\title{
Effect of Salix Tetrasperma Roxb. Extract on The Value of Feed Conversion Ratio, Carcass Weight, and Abdominal Fat Content of Broiler Chicken with Heat Stress Condition
}

\author{
Sugito Sugito ${ }^{1 *}$, Erdiansyah Rahmi $^{1}$, Mira Delima $^{2}$, Nurliana Nurliana ${ }^{1}$, Rusli Rusli ${ }^{1}$, and $M$. Isa ${ }^{1}$ \\ ${ }^{1}$ Faculty of Veterinary Medicine, Universitas Syiah Kuala \\ ${ }^{2}$ Faculty of Agriculture, Department of Animal Husbandry, Universitas Syiah Kuala
}

\begin{abstract}
Heat stress on broiler chickens has an impact on the value of feed conversion ratio (FCR), carcass weight, and abdominal fat content. These impacts can be reduced by administering plant extracts, such as salix plant extract. However, the effect of this plant extract on normal condition is still unknown. This study aimed to determine the effect of salix extract to the value of feed conversion ratio, carcass weight, and abdominal fat content in chickens with heat stress and compared with chickens in normal conditions. This study used 30 samples of 21-day old broiler chickens. This research was conducted using a complete factorial randomized design with $2 \times 3$ treatment factors and 5 repetitions. The first factor consisted of two treatment conditions, namely heat stress (HS) and no heat stress (nHS), while the second factor consisted of three doses of salix extract treatment, dose 0 (ES-0), 50 (ES-50), and 100 (ES-100) mg/L of drinking water. Heat stress was conducted by increasing the temperature of the cage to $34 \pm 1{ }^{\circ} \mathrm{C}$ for 4 hours per day. Salix extract was added in drinking water and given 2 hours before the temperature reached $34 \pm 1{ }^{\circ} \mathrm{C}$. Chickens without heat stress were kept in the cage at $25 \pm 1{ }^{\circ} \mathrm{C}$ using air-condition (AC). Data were analyzed using two way ANOVA using SPSS 20. The results showed that administration of salix extract on heat stress chickens did not affect the FCR value and carcass weight, but had a significant effect $(\mathrm{P} \leq 0.05)$ on abdominal fat weight. Fat content in the abdominal was higher $(\mathrm{P} \leq 0.05)$ in chickens with heat stress and given salix extract than non heat stress.
\end{abstract}

Keywords: heat stress, FCR, carcass weight, salix extract, abdominal fat.

\section{Introduction}

Changes on the environment temperature where the broiler chickens raising have an impact on its productivity. When a 21-day-old broiler chicken, they required optimal temperature between 15 to $27^{\circ} \mathrm{C}$ with the relative humidity ranging from 60 to $70 \%$ to be able to produce optimally according to its genetic potential. For broiler chickens aged over 21 days old who experienced high temperature $\left(>27^{\circ} \mathrm{C}\right)$ and high humidity $(>70 \%)$ can cause heat stress. Various reports indicated that heat stress in chickens can result in weight loss, increase feed conversion ratio, and metabolic disorders [1].

Various effors have been conducted to reduce the impact of heat stress on broiler chickens, including by providing plant extract supplements as antistress, both in feed or drinking water [2]. Some researchers reported that administration of plant extracts can significantly improve the negative effects of heat stress on broiler chickens $[3,4]$. The application of salix (Salix tetrasperma Roxb) leaf extract to chickens can reduce the negative effects of heat stress [5]. Salix plant extracts can also reduce cholesterol in meat [6]. It is suspected that salix extract works to reduce the impact of heat stress on broiler chickens through its antioxidant activity. In salix plant extracts there are various bioactive compounds so that they can be used as a source of potential natural antioxidant bioactive compounds [7,8]. The presence of various compounds is thought to affect reducing lipid formation, carcass weight loss, and reducing the feed conversion ratio in stressed or non-heat stressed chickens. This study was conducted to determine the effect of salix extract on the value of feed conversion ratio, carcass weight, and abdominal fat in broiler chickens who were experiencing heat stress and who were not given heat stress.

\section{Materials and Methods}

\subsection{Study Animals}

This study used 30 samples of 21-day-old broiler chickens. Chickens were adapted from the age of 15 days and were then randomized and kept in individual cages of $40 \times 30 \times 40 \mathrm{~cm}$ equipped with a feed and water troughs. Feed and drinking water are given throughout the day (ad libitum). The nutritional content of feed was $17.5 \%$ crude protein, $4.5 \%$ crude fat, $5 \%$ crude fiber, $13 \%$

*Corresponding author: sugitofkhunsyiah@unsyiah.ac.id 
ash, $3.25 \%$ calcium, and $6 \%$ phosphorus. The main feed ingredients contain corn, rice bran, soybean cake, palm oil, sea salt, premix, vitamins, and minerals.

\subsection{Methods}

This study used a complete factorial randomized design $2 \times 3$ (6 treatment combinations). The first factor consists of two treatment conditions, namely heat stress (HS) and non-heat stress (n-HS) conditions, while the second factor consists of three doses of salix extract (ES) treatment, namely dose $0 \mathrm{mg} / \mathrm{L}$ (ES -0), $50 \mathrm{ng} / \mathrm{L}$ (ES-50), and 100 $\mathrm{ng} / \mathrm{L}$ (ES-100) of drinking water. Each treatment combination consisted of 5 replications. Heat stress was given by increasing the temperature of the cage room at $34 \pm 1{ }^{\circ} \mathrm{C}, \quad 4$ hours per day (12:00 to $16: 00$ hours) for 7 consecutive days. Salix extract was given when the temperature of the cage was raised and when it reaches 34 $\pm 1^{\circ} \mathrm{C}$. The chickens were fasted for 2 hours (8:00 to 10:00 ) before given the salix extract in the drinking water. For $\mathrm{n}$-HS of chickens group, the temperature treatment in a cage was set in the range of $25 \pm 1^{\circ} \mathrm{C}$. The temperature was controlled with an air conditioner (AC). The food and water that consumed by the chiken have been weighed every day. The first weighing was done at the beginning of this study and just before slaughtered. After the chickens were treated for 7 days, all chickens were slaughtered for abdominal fat measurements. Data were analyzed using a factorial completely randomized design ( $2 \times 3)$ using SPSS 20.

\section{Results and Discussion}

\subsection{Feed conversion ratio (FCR)}

The average FCR value of each treatment is presented in Table 1. The application of salix leaf extract to broiler chickens that experience heat stress (HS) and not heat stress (n-HS) did not affect the FCR value. This showed that the administration of salix extract in both conditions of chickens did not effect the digestion process of feed ingredients in the digestive tract. The presence of several compounds in plant extracts under certain conditions can affect the impaired absorption of nutrients [9]. The content of bioactive compounds in Salix tetrasperma Roxb. leaf extracts contains several compounds such as tannins, saponins, flavonoids, triterpenes, phenol compounds, and sterols [10,7]. The tannin and saponin compounds have been known to be antinutrients [11]. Antinutrient content was notsuspected to interfere with the absorption of nutrients. It could also be that salix extract contains bioactive compounds that have stomachic and adaptogenic activities so that the activity of feed consumption was not disrupted.

The data in Table 1 showed that the higher dose of salix extract given the lower the FCR value. This also indicates that there was a tendency that the administration of salix leaf extract in drinking water to a dose of $100 \mathrm{~m}$ $/ \mathrm{L}$ can increase feed use. The results of other studies have proven that the administration of plant extracts can affect increasing feed use and decreasing FCR [12]. The significance of the results of the administration of salix extract to FCR in this study was assumed to belong and the time of administration was relatively short only 7 days and 4 hours per day.

Table 1. The average of FCR value after being given salix leaf extract to chickens experiencing heat stress and no heat stress for 7 days in 4 hours per day.

\begin{tabular}{llll}
\hline & \multicolumn{3}{c}{ FCR value } \\
\cline { 2 - 4 } Treatment & ES-0 & ES-50 & ES-100 \\
\hline Heat Stress & $1.43 \pm 0.08$ & $1.40 \pm 0.09$ & $1.38 \pm 0.08$ \\
non Heat Stress & $1.39 \pm 0.09$ & $1.39 \pm 0.08$ & $1.37 \pm 0.02$ \\
\hline
\end{tabular}

\subsection{Carcass Weight}

Data in Table 2 shows the average of carcass weight in each treatment. The highest average carcass weight (980.3 g) was found in the treatment of chickens who were not suffering from heat and given salix extract $50 \mathrm{mg} / \mathrm{L}$ in drinking water (nHS-ES-50) while the lowest carcass body weight $(920.4 \mathrm{~g})$ was found in chickens who were given heat stress without being given salix extract. Giving salix extract to chickens that are experiencing and not experiencing heat stress did not affected the carcass weight. This result is different from previous studies that Salix extract can inhibit the body weight reduction of heat stressed chickens [5]. The difference of the results can caused by the his differences in chicken age, and days or time of administration of salix extract.

Table 2. The average of carcass weight after being given salix leaf extract to chickens experiencing heat stress and no heat stress for 7 days in 4 hours per day.

\begin{tabular}{llll}
\hline \multirow{2}{*}{ Treatment } & \multicolumn{3}{c}{ Carcass Weight $(\mathrm{g})$} \\
\cline { 2 - 4 } & ES-0 & ES-50 & ES-100 \\
\hline Heat Stress & $920.4 \pm 74.9$ & $977.8 \pm 74.2$ & $955.6 \pm 47.5$ \\
non Heat Stress & $939.8 \pm 73.5$ & $980.8 \pm 88.7$ & $962.8 \pm 42.2$ \\
\hline
\end{tabular}




\subsection{Abdomen Fat Weight}

The effect of giving salix extract on abdominal fat weight in broilers who experienced and did not experience heat stress after 7 days of treatment is presented in Table 3.
The highest value of abdominal fat weight was found in chickens that were given salix 50 extracts and $100 \mathrm{mg} / \mathrm{L}$ of drinking water, while the lowest abdominal fat weight in chicken treatments was not given heat stress and was given salix extract $100 \mathrm{mg} / \mathrm{l}$ of drinking water.

Table 3. The average of abdomen fat weight after being given salix leaf extract to chickens experiencing heat stress and no heat stress for 7 days in 4 hours per day

\begin{tabular}{llll}
\hline \multirow{2}{*}{ Treatment } & \multicolumn{3}{c}{ Abdomen Fat Weight $(\mathrm{mg})$} \\
\cline { 2 - 4 } & ES-0 & ES-50 & ES-100 \\
\hline Heat Stress & $18.00 \pm 2.00^{\mathrm{aAB}}$ & $22.00 \pm 1.58^{\mathrm{bA}}$ & $22.00 \pm 2.55^{\mathrm{bA}}$ \\
non Heat Stress & $19.00 \pm 1.00^{\mathrm{aA}}$ & $19.60 \pm 2.30^{\mathrm{aA}}$ & $17.40 \pm 1.82^{\mathrm{bB}}$ \\
\hline
\end{tabular}

The administration of salix extract (doses of 50 and $100 \mathrm{mg} / \mathrm{l}$ of drinking water) to chickens experiencing heat stress significantly $(\mathrm{P}>0.05)$ increases the weight of abdominal fat but the giving of salix extract $(100 \mathrm{mg} / \mathrm{l}$ of drinking water) to chickens that did not experience heat stress significantly $(\mathrm{P}>0.05)$ can reduce abdominal fat weight. Increased abdominal fat weight in chickens is thought to be caused by an adaptive arrangement in heat stress conditions; the energy is stored as fat more than usual, the less heat is produced, so less heat needs to be released from the body [13]. An increase in abdominal fat weight in broiler chickens under heat stress and given salix extract indicates that the bioactive compounds contained in the extract have not been working effectively. Previous research reports that plant extracts that contain lots of antioxidants can reduce heat stress. Salix tetrasperm Roxb. has good potential as a source of antioxidant agents $[7,8,14]$.

On the other hand, there was a decrease in abdominal fat weight in broiler chickens that were not given heat stress and were given salix extract. This is allegedly due to the effect of the bioactive compounds (flavonoid glucoside) that can increase lipolysis in fat cells [15] or anti-adipogenic activity [16]. How the two conditions of chicken's environmental temperature can cause differences in the work effects of salix extract in affecting the activity of abdominal fat or lipid metabolism needs to be a concern for further research.

\section{Conclusion}

Salix leaf extract dose of 50 and $100 \mathrm{mg} / \mathrm{l}$ of drinking water for 7 days in 4 hours per day in chickens non heat stress or who experience heat stress, did not affect the FCR value and carcass weight. The effect of salix extract can increase the weight of abdominal fat in heat stressed chickens and conversely reduce the weight of abdominal fat in chickens non heat stress.

\section{Acknowledgments}

The results of this study are part of the implementation of research grand of the Lektor Kepala (Number: 111/UN11.2/PP/PNBP/SP3/2019) in 2019. For that, thanks to the Rektor of Universitas Syiah Kuala who has provided grants in accordance with the Letter of
Appointment of this research grand. Acknowledgments were also conveyed to those who have helped carry out this research.

\section{References}

1. Lara LJ, Rostagno MH : Impact of heat stress on poultry production. Animals. 2013; 3: 356-369.

2. Fotina AA, Fisinin VI, Surai PF : Recent developments in the use of natural antioxidants to improve chicken meat production and quality . Bulg. J. Agric Sci. 2013; 19: 889-896.

3. Al-Fataftah AR, Abdelqader A : Effect of salix babylonica, populus nigra and eucalyptus camaldulensis extracts in drinking water on performance and heat tolerance of broiler chickens during heat stress. American-Eurasian J. Agric \& Environ. Sci. 2013; 13(10): 1309-1313

4. Selvam R, Suresh S, Saravanakumar M, et al .: Alleviation of heat stress by a polyherbal formulation, phytocee TM: impact on zootechnical parameters, cloacal temperature, and stress markers. Pharmacognosy Res. 2018; 10 (1): 1-8.

5. Sugito, Hambal M, Isa M, et al.: Administration of Salix tetrasperm extract combined with extract of turmeric and neem to improve egg quality of chicken reared under heat stress. JITV. 2015; 20 (3): 193-199.

6. Saracila M, Panaite TD, Vlaicu PL, et al.: Dietary willow bark extract for broilers reared under heat stress. The UASVM Anim Sci Biotechnol Bulletin. 2018; 75 (2): 9298.

7. El-Deputy EA, El-Sayed S, Abdel-Hameed, et al.: Identification of the chemical composition of the methanolic extract of Salix tetrasperm Roxb . using LC-ESI-MS and evaluating its potential as an antioxidant agent. Der Pharma Chemica. 2015; 7 (2): 168-177.

8. Januarti R, Adlis $\mathrm{S}$, Mai: Isolation of flavonoid compounds and antioxidant activity of salix tetrasperm roxb. leaves. Indonesia J Fundam Appl Chem. 2019; 4 (2): 42-46.

9. Gemede HF, Ratta N: Antinutritional factors in plant foods: Potential health benefits and adverse effects. Int J Nutr Food Sci. 2014; 3 (4): 284-289.

10. Virupaksha JH, Nadendla RR, Kumar MS, et al. :: Effect of Salix tetrasperm Roxburgh leaf extracts on central nervous system activities. Res $J$ Pharm Biol Chem Sci. 2016; 7 (4): 2060-2064. 
11. Tadele Y: Important anti-nutritional substances and inherent toxicants of feeds. Food Sci Qual Manage. 2015; 36: 40-47.

12. Omar JA, Hejazi A, Badran R: Performance of broilers supplemented with natural herb extracts. Open J Anim Sci. 2016; 6: 68-74.

13. Lu Q, Wen J, Zhang H: Effect of chronic heat exposure on fat deposition and meat quality in two genetic types of chicken. Poult Sci. 2007; 86: 1059-1064.

14. El-Shazly A, El-Sayed A, Fikrey E: Bioactive secondary metabolites from Salix tetrasperm Roxb. Z. Naturforsch. 2012; 67c: 353 - 359.
15. Han LK, Sumiyoshi M, Zhang J, et al.: Anti-obesity action of Salix Matsudana leaves (Part 1).Anti-obesity action by polyphenols of Salix matsudana in high fat - diet treated rodent animals. Phytother Res .2003; 17 (10): 1188-1194.

16. Lee M, Lee SH, Kang J, et al.: Salicortin-Derivatives from Salix pseudo-lasiogyne twigs inhibit adipogenesis in 3T3-L1 cells via modulation of $\mathrm{C} / \mathrm{EBP \alpha}$ and SREBP1c dependent pathway. Molecules 2013; 18: 10484-10496. 